\section{THE NEW GEOLOGICAL MAP OF RUSSIA ${ }^{1}$}

GEOLOGISTS will be glad to hear of the appear$G$ ance of the first sheet of the "Geological Survey of Russia," published by the Geological Committee on the scale of 10 versts to an inch. It comprises nearly the whole of the Government of Yaroslav and the eastern parts of Tver, between $57^{\circ} \mathrm{o}^{\prime}$ and $57^{\circ} 42^{\prime} \mathrm{N}$. lat., and $43^{\circ} 10^{\prime}$ to $47^{\circ} 40^{\prime} \mathrm{E}$. long., corresponding thus to Sheet 56 of the General Staff Map of Russia. This region, which is watered by the Upper Volga, the Mologa, and the Sheksna, is an undulating plain, the highest points of which, close to Bejetsk, reach 700 feet above the scalevel, gently sloping cast and west to a level of from $35^{\circ}$ to 420 feet. It has been dealt with first on account of a series of geological explorations which have already been made within its limits. It was visited by Blasius, Murchison, Keyserling, and Barbot-de-Marny, and careful explorations have been undertaken during the last few years within the limits of the province of Yaroslav, under the direction of its Provincial Assembly and Statistical Committee, by MM. Schurovsky, Piktorsky, Eremeyeff, Dittmar, Kryloff, and Nikitin.

The map, which has been prepared by M. Nikitin, is very carefully printed, and will be the more welcome to European geologists as all important names and explanations are given in French, side by side with the Russian text. The colours and the explanatory letterpress are in conformity with the recommendations of the International Geological Congress. A quarto volume, in Russian, by M. Nikitin, with plates and drawings, accompanies the map, the whole being summed up in German at the end of the volume.

The first thing which strikes one on looking at the map is the very great space covered with the gray colour of the Quaternary deposits. A greenish patch of Jurassic rocks in the middle of the map, several patches of Trias on its borders, and a very small Carboniferous patch, altogether hardly cover one-third of the surface; the remainder representing the "Boulder Clay, which conceals deposits of unknown age." The thick sheet of Boulder Clay will be for a long time the stumbling-block of Russian geologists. Natural sections are found only on the banks of the greater rivers, while the valleys of the smaller ones, to their very bottom, are cut through Quaternary deposits. Even the two railways that cross the space covered by the map have been laid without excavations of any importance to the geologist; and no artificial excavations worthy of notice are to be found in the whole area.

As to the geological description which accompanies the map, it is full of interest. The Carboniferous deposits which are denuded over a very limited space in the north-west, belong to the Upper series, characterised by Spirifer mosquensis. They probably extend throughout the region in nearly horizontal strata gradually inclined towards the east ; but they are concealed by the Variegated Marls which are the subject of so lively a controversy among Russian geologists, and which are considered by the author as belonging to the Trias, contrary to the opinion of the Kazan geologists, who consider them Permian. Although appearing on the surface only in isolated islands, these Marls probably also extend throughout the Yaroslav region; the salt-springs at least, which appear at many places, and which usually take their origin, in Russia, either in the Devonian or in the Variegated Marls, seeming to indicatc a great extension of these deposits. The Jurassic formations appear now (as throughout Middle Russia) only as sporadic islands, which are remains of a widely-extended strata destroyed by denudation; the Jurassic sea, according to the author, extending at least as far north as the latitude of Tver. The Jurassic deposits, which have been, like the Variegated x "General Geological Map of Russia." Sheet 56, Yaroslav, \&c. BBy S. Nikitin. (Memoirs of the Geological Committee, vol, i. No. 2. "St. Petersburg, 1884.)
Marls, the subject of special monographs by M. Nikitin, are represented in the Yaroslav region; the lower ones by the Callovian and the Oxford Clay, the two chief subdivisions of the former being characterised respectively by Cadoceras Milascherici and Quenstedioceras I.enchi, and those of the latter by Cardioceras cordatum and $C$ alternans. The Upper Jurassic is represented by the "Volga Series," Lower and Upper, respectively characterised by Perisphinctes virgatus, Oxynoticeras fulgens, and Olcostephanus subditus. They are invariably covered with a sheet of sands (like the Jurassic of Central Russia), which seems to have been a littoral deposit accumulated during the retreat of the Jurassic sea.

A very interesting chapter is devoted to the Quaternary deposits of Yaroslav and Central Russia. The thick sheet of Boulder Clay which covers Central and North-West Russia, and contains erratics from Finland and Olonetz, as also from those regions which the erratics had to cross on their way from the north, has long been a puzzle to Russian geologists. Within the limits of the map, it appears with its usual characters, that is, those of a layer 8 to $10 \mathrm{~m}$. thick, spread without interruption over the country-over the watersheds as well as the valleys - without any traces of stratification or even of striation by water : the thickest boulders and the finest particles appearing closely mixed together without bearing any traces of sorting by water-currents. As to the boulders, they are of all possible sizes, from a grain of quartz to masses 2 and $3 \mathrm{~m}$. in diameter. While crystalline rocks and schists from Finland and Olonetz are prevalent, local boulders-Carboniferous and sometimes Jurassic-are also not absent, especially in the lower strata. The boulders have a tendency towards a disposition in ridges which run from north-west to southeast, crossing the rivers, or rising sometimes in the shape of moraines, or eskers of great size. A sheet of boulderbearing sand, with traces of stratification, appears at many places beneath the Boulder Clay, which passes also in its upper parts into an unstratificd sand with boulders.

Such being the character of these deposits, it is obvious that the theory fails which tries to explain them by floating ice, as does also Prof. Trautschold's theory of "Eluvium." The author accepts, therefore, the theory now gencrally adopted by geologists, and specially advocated for Germany by Berendt, Penck, and Bernhardi, and for Russia by P. Krapotkin, and considers the Russian Boulder Clay as an equivalent of the Krosstenslera of Sweden. Like the British Till, it is no doubt the bottom-moraine of the great ice-sheet which covered Northern Germany and Russia, without reaching the Ural Mountains, during the iceperiod. This period succeeded to a relatively mild climate, when the plains of Moscow were covered with thick oak and maple forests, inhabited by the mammoth and the rhinoceros, which were compelled by the icesheet slowly advancing from the north-west to emigrate east and south. The Locss of Southern Russia, and the Loess-like deposits of the intermediate region, were probably contemporary with the glaciation of the north.

Another chapter is devoted to the formation of rivers in European Russia, and to the great processes of denudation in the later parts of the Ouaternary period. This subject has been keenly discussed of late by Russian geologists. The author is to be congratulated on the scientific manner in which he has laid the basis for a discussion of the three important questions - as to the Variegated Marls, the Boulder Clay, and the more recent alluvial deposits - with which he has had to deal in this first fascicule of the Geological Survey of Russia.

\section{EARTHQUAKES}

THOSE observers who have undertaken the detailed study of a region severely injured by an earthquake are well acquainted with the difficulties that attend on 